\title{
Pendidikan gizi dan pesan gizi melalui short message service terhadap pengetahuan, perilaku, dan kepatuhan ibu hamil minum tablet besi
}

\author{
Nutrition education and nutrition message through short message service to knowledge, behavior and \\ compliance of pregnant mothers with taking iron tablet
}

Mars Khendra Kusfriyadi', Hamam Hadi', Anis Fuad ${ }^{3}$

\begin{abstract}
Background: Low compliance as one cause of high prevalence of anemia in Indonesia is mainly due to forgetfulness. Nutrition education and short message service (SMS) are expected to become media to send nutrition message and remind pregnant mothers of taking iron tablet.

Objective: To identify impact of nutrition education and nutrition message through SMS to knowledge, behavior and compliance of pregnant mothers with taking iron tablet.

Method: The study was a quasi experiment that used pre and post test control/non equivalent control group design involving 3 groups of experiment, i.e. nutrition education only, nutrition education and SMS, and control as comparator. Subject of the study consisted of 121 pregnant mothers. The study was carried out from November 2009 to April 2010 at Palangka Raya Municipality in Pahandut, Kayon and Tangkiling Health Centers. Statistical analysis was performed by using paired t-test, ANOVA, Tukey test, and multivariate test.

Result: Pregnant mothers that got nutrition education and SMS intervention significantly improved their knowledge and behavior $(p<0.05)$. Pregnant mothers that got nutrition education and SMS had knowledge 18 point higher (coef $=18.26)$, behavior 4 point better (coef=4.07) and probability 4 times more compliant than the control group $(O R=3.79 ; p=0.03)$. Nutrition education and SMS intervention could increase compliance and significantly affect increase of hemoglobin ( $\mathrm{Hb}$ ) level up to $1.3 \mathrm{~g} / \mathrm{dl}(\mathrm{p}<0.05)$. Increase of $\mathrm{Hb}$ level went in line with increase of compliance (dose-response) in pregnant mothers with preliminary $\mathrm{Hb}$ level $<11 \mathrm{~g} / \mathrm{dl}$. Meanwhile in pregnant mothers with preliminary $\mathrm{Hb}$ level $\geq 11 \mathrm{~g} / \mathrm{dl}$, increase of Hb level was statistically significant when compliance reached $\geq 90 \%$.

Conclusion: Pregnant mothers that got nutrition education and SMS had better knowledge, behavior and compliance with taking iron tablet than those that only got nutrition education and the control group. High compliance could significantly increase $\mathrm{Hb}$ level.
\end{abstract}

KEY WORDS: anemia, pregnant mothers, knowledge, behavior, compliance, hemoglobin level, SMS, nutrition education

\begin{abstract}
ABSTRAK
Latar belakang: Kepatuhan konsumsi tablet besi yang rendah adalah salah satu penyebab tingginya prevalensi anemia pada ibu hamil di Indonesia yang sebagian besar disebabkan oleh faktor lupa. Pendidikan gizi disertai SMS diharapkan menjadi media penyampaian pesan gizi dan reminder minum tablet besi yang berdampak pada perubahan kadar $\mathrm{Hb}$ ibu hamil.

Tujuan: Mengetahui pengaruh pendidikan gizi dan pesan gizi melalui SMS terhadap pengetahuan, perilaku, kepatuhan, dan kadar Hb ibu hamil.

Metode: Jenis penelitian ini adalah quasi ekperimen dengan rancangan sebelum dan sesudah intervensi menggunakan kelompok pembanding eksternal yang dilaksanakan pada bulan November 2009-April 2010 di Puskesmas Pahandut, Puskesmas Kayon, dan Puskesmas Tangkiling Kota Palangka Raya. Subjek penelitian berjumlah 121 orang ibu hamil yang dibedakan menjadi 3 kelompok perlakuan, yaitu pendidikan gizi saja, pendidikan gizi disertai SMS, dan kontrol sebagai pembanding. Analisis statistik dilakukan dengan menggunakan paired t-test, ANOVA, Tukey test, dan multivariat.

Hasil: Ibu hamil yang mendapat intervensi pendidikan gizi disertai SMS mengalami peningkatan pengetahuan dan perilaku yang berbeda secara bermakna $(p<0,05)$. Ibu hamil yang mendapat pendidikan gizi disertai SMS, 18 point lebih tinggi pengetahuannya (coef=18,26), 4 point lebih baik perilakunya (coef=4,07), dan memiliki kemungkinan lebih patuh 4 kali dibandingkan kontrol $(O R=3,79 ; p=0,03)$. Intervensi pendidikan gizi disertai SMS mampu meningkatkan kepatuhan
\end{abstract}

\footnotetext{
${ }^{1}$ Korespondensi: Politeknik Kesehatan Kementerian Kesehatan Palangkaraya Jurusan Gizi, Jl. George Obos No. 30, Palangkaraya, e-mail: mars_ khendra@yahoo.com

2 Minat Utama Gizi Kesehatan, Program Studi S2 IImu Kesehatan Masyakarat, Fakultas Kedokteran Universitas Gadjah Mada, Jl. Farmako, Sekip Utara, Yogyakarta 55281, e-mail: hamamhadi99@gmail.com

${ }^{3}$ Minat Utama Sistem Informasi Manajemen Kesehatan, Program Studi S2 IImu Kesehatan Masyakarat, Fakultas Kedokteran Universitas Gadjah Mada, Jl. Farmako, Sekip Utara, Yogyakarta 55281
} 
sehingga berpengaruh bermakna terhadap peningkatan kadar $\mathrm{Hb}$ hingga 1,3 g/dl ( $p<0,05)$. Peningkatan kadar $\mathrm{Hb}$ seiring dengan semakin meningkatnya kepatuhan (dose-response) dengan kadar $\mathrm{Hb}$ awal < $11 \mathrm{~g} / \mathrm{dl}$ sedangkan pada ibu hamil dengan kadar Hb awal $\geq 11 \mathrm{~g} / \mathrm{dl}$, peningkatan kadar Hb bermakna apabila kepatuhan mencapai $\geq 90 \%$.

Simpulan: Ibu hamil yang mendapat pendidikan gizi dan pesan gizi melalui SMS memiliki pengetahuan, perilaku, dan kepatuhan minum tablet besi lebih baik dibandingkan ibu hamil yang hanya mendapatkan pendidikan gizi saja dan kontrol. Kepatuhan yang tinggi secara bermakna dapat meningkatkan kadar $\mathrm{Hb}$.

KATA KUNCI: anemia, ibu hamil, pendidikan gizi, SMS, pengetahuan, perilaku, kepatuhan, kadar hemoglobin

\section{PENDAHULUAN}

Anemia yang disebabkan defisiensi zat besi merupakan kelainan gizi yang paling sering ditemukan di dunia dan menjadi masalah kesehatan masyarakat yang bersifat epidemik. Di negara berkembang, permasalahan defisiensi zat besi cukup tinggi. Rata-rata satu di antara dua orang ibu hamil menderita anemia (1). Menurut data riset kesehatan dasar (Riskesdas) tahun 2007 diketahui bahwa prevalensi ibu hamil yang menderita anemia mikrositik hipokromik sebesar $59 \%$ dan $10,3 \%$ mengalami anemia makrositik, serta $30,8 \%$ menderita anemia jenis lainnya (2). Angka prevalensi anemia ibu hamil di Indonesia (59\%) termasuk dalam kategori masalah kesehatan masyarakat tingkat berat (severe public health problem) (3).

Di Indonesia, telah dilakukan distribusi tablet besi 120 mg per hari selama 3 bulan bagi setiap ibu hamil dan telah dilaksanakan selama periode 10 tahun. Namun, prevalensi anemia defisiensi zat besi tetap tinggi (1). Prevalensi anemia pada ibu hamil belum berhasil diturunkan sampai angka yang menggembirakan (4). Angka kematian maternal sebagai salah satu indikator keberhasilan program penurunan anemia ibu hamil juga belum mencapai angka yang diharapkan (5). Kontribusi anemia terhadap kematian ibu di Indonesia mencapai $56-68 \%$. Dengan demikian, sebagian besar kematian ibu di Indonesia sebenarnya dapat dicegah dengan cara menurunkan prevalensi anemia (4).

Beberapa hasil penelitian menyatakan faktor penyebab ketidakberhasilan program suplementasi tablet besi di Indonesia diantaranya adalah rendahnya kepatuhan ibu hamil mengonsumsi tablet besi (6-10) dan persepsi yang salah, baik dikalangan masyarakat maupun petugas kesehatan (5). Faktor lupa menjadi alasan utama ketidakpatuhan ibu hamil dalam mengonsumsi tablet besi. Persentase faktor lupa dari beberapa hasil penelitian berkisar antara 53,9\%; 47,98\%; dan 53,85\% $(4,11,12)$. Upaya untuk mengatasi permasalahan di atas dapat diminimalisasi dengan kehadiran atau keterlibatan orang lain seperti suami dan keluarga $(5,4,13,12)$ atau dengan media yang dapat mengingatkan ibu hamil untuk mengonsumsi tablet besi (7). Ibu hamil yang mendapat pengawasan suami 8,5 kali lebih patuh dalam mengonsumsi tabet besi daripada ibu hamil yang hanya mendapatkan pengawasan dari bidan (4).

Kepatuhan terhadap suplementasi tablet besi dapat ditingkatkan dengan instruksi yang jelas terhadap intake tablet besi dan memberikan pendidikan kepada ibu hamil tentang keuntungan-keuntungan dari tablet besi tersebut (10). Hal ini dapat dilakukan dengan pendidikan kesehatan melalui media massa atau dari petugas kesehatan setempat. Proses pendidikan kesehatan atau promosi kesehatan dapat dilakukan melalui beberapa cara, yaitu pengajaran, pelatihan, konseling, konsultasi, dan melalui media (14).

Penggunaan short message service (SMS) sebagai reminder dibidang kesehatan cukup populer di luar negeri namun masih kurang populer di Indonesia. Beberapa hasil penelitian yang telah dipublikasikan diantaranya melaporkan bahwa intervensi melalui mobile phone text messaging dapat meningkatkan angka berhenti merokok dan program ini sangat potensial dalam membantu para perokok muda untuk berhenti dengan syarat punya keinginan kuat untuk berhenti merokok, berasal dari dalam dirinya sendiri (personalized), sesuai umur, dan tidak tergantung lokasi (15). Penelitian menggunakan SMS sebagai reminder juga dilakukan di Seven Primary Care Clinics Malaysia dengan kesimpulan sistem pengingat melalui SMS (text messaging reminder system) efektif dalam meningkatkan jumlah kedatangan (attendance rate) di klinik tersebut (59\%) dan lebih cost effective daripada diingatkan melalui mobile phone (16). SMS reminder juga dilaporkan dapat menurunkan 38\% ketidakhadiran pasien mata untuk pemeriksaan kembali ke klinik. SMS reminder lebih cost effective daripada sistem pengingat tradisional dan lebih efisien dalam hal tenaga (17).

Berdasarkan penjelasan di atas maka penelitian ini dilakukan untuk mengetahui pengaruh pendidikan gizi dan pesan gizi yang dikirimkan melalui SMS terhadap pengetahuan, perilaku, kepatuhan minum tablet besi, dan kadar hemoglobin $(\mathrm{Hb})$ ibu hamil di Kota Palangka Raya.

\section{BAHAN DAN METODE}

Penelitian ini merupakan penelitian eksperimen semu (quasy experiment) dengan rancangan sebelum dan sesudah intervensi menggunakan kelompok pembanding eksternal yang dilaksanakan di Kota Palangka Raya pada bulan November 2009 sampai dengan bulan April 2010. Pemilihan puskesmas berdasarkan data cakupan tablet besi ( $\mathrm{Fe} 1$ dan $\mathrm{Fe} 3$ ) yang rendah dalam lingkup Kota Palangka Raya, yaitu Puskesmas Pahandut (22,3\% 


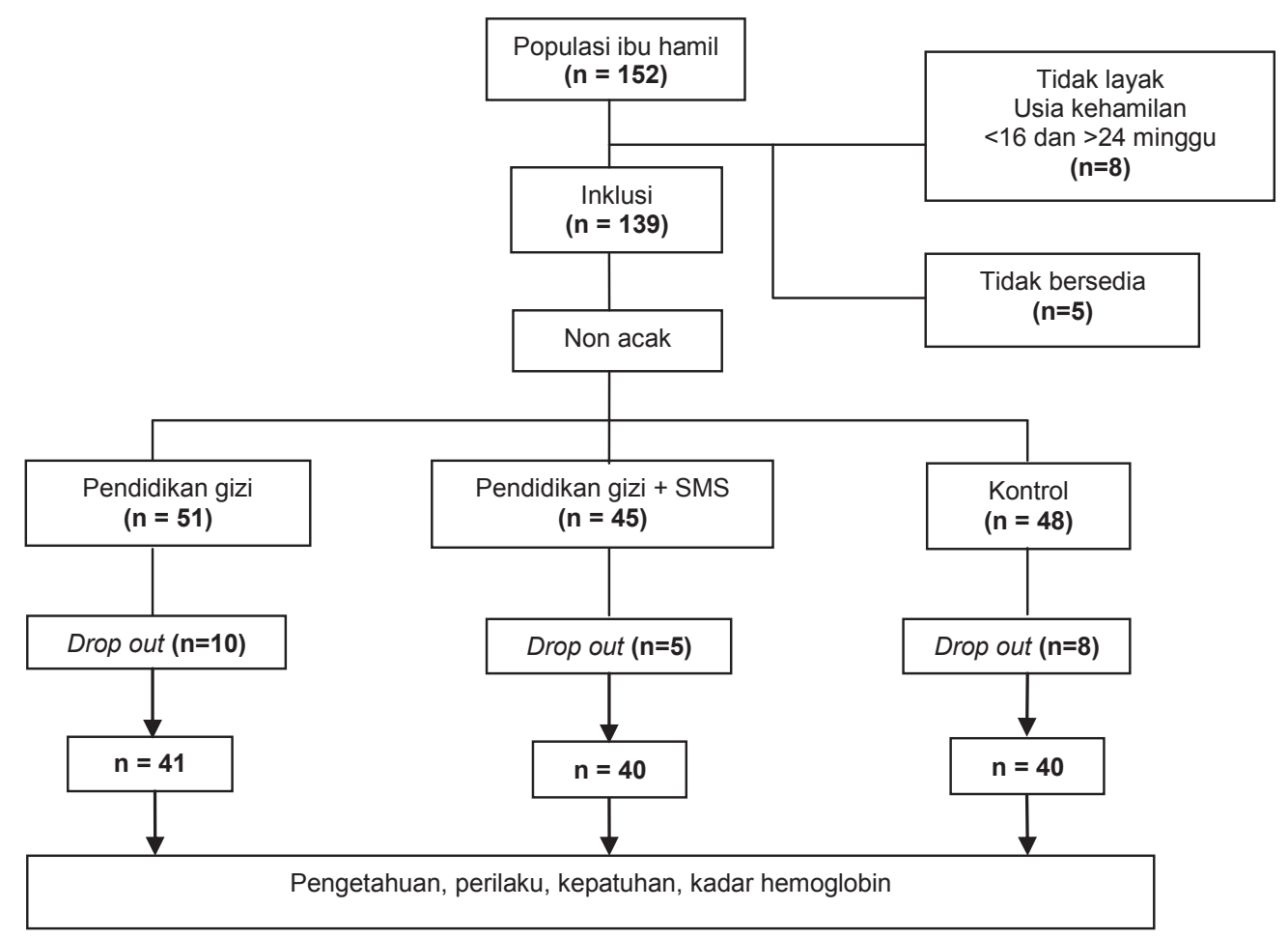

Gambar 1. Profil subjek penelitian

dan 23\%), Puskesmas Kayon (63\% dan 57,6\%), dan Puskesmas Tangkiling (68\% dan 59,8\%) (18). Besar sampel minimal dalam penelitian ini dihitung menggunakan rumus pengujian hipotesis rata-rata dua populasi (19) dengan delta kadar $\mathrm{Hb}=3 \mathrm{~g} / \mathrm{dl}$, standar deviasi=4,5 g/dl (4), tingkat kemaknaan $5 \%$, dan power $90 \%$ sehingga diperoleh jumlah sampel minimal untuk masing-masing kelompok sebanyak 39 orang dan penambahan $10 \%$ dari jumlah sampel untuk mengantisipasi sampel yang drop out selama penelitian. Dengan demikian, besar sampel minimal dalam penelitian ini sebesar 43 orang untuk setiap kelompok. Teknik pengambilan sampel secara purposive sampling dengan kriteria inklusi yaitu memiliki handphone (semua merk), usia kehamilan 16-24 minggu, tidak buta huruf, bisa membaca dan menulis, dan bersedia menjadi subjek penelitian (informed consent) sedangkan kriteria eksklusinya adalah ibu hamil dengan komplikasi penyakit dan anemia tingkat berat.

Berdasarkan data kunjungan ibu hamil periode Oktober-November 2009 di masing-masing puskesmas diketahui total populasi ibu hamil sebanyak 152 orang. Namun, subjek penelitian yang memenuhi kriteria inklusi sebesar 139 orang dengan rincian 51 orang ibu hamil di wilayah kerja Puskesmas Pahandut, 40 orang ibu hamil di wilayah kerja Puskesmas Tangkiling, dan 48 orang ibu hamil di wilayah kerja Puskesmas Kayon. Selama penelitian berlangsung, drop out subjek penelitian terjadi dengan berbagai alasan diantaranya berpindah tempat, tidak diizinkan suami, dan melahirkan premature. Dengan demikian, jumlah subjek penelitian yang mengikuti hingga akhir penelitian adalah 121 orang dengan rincian 41 orang ibu hamil di wilayah kerja Puskesmas Pahandut, 40 orang ibu hamil di wilayah kerja Puskesmas Tangkiling, dan 40 orang ibu hamil di wilayah kerja Puskesmas Kayon (Gambar 1).

Penetapan lokasi penelitian dilakukan secara random allocation dan memperhatikan jarak antar wilayah dengan tujuan meminimalisasi kontaminasi antar subjek selama penelitian berlangsung. Berdasarkan intervensi yang diberikan, subjek dibedakan menjadi 3 kelompok penelitian, yaitu kelompok perlakuan satu $\left(P_{1}\right)$ merupakan kelompok ibu hamil di Puskesmas Pahandut yang diintervensi dengan pendidikan gizi saja di awal penelitian; kelompok perlakuan dua $\left(\mathrm{P}_{2}\right)$ merupakan kelompok ibu hamil di Puskesmas Tangkiling yang diintervensi dengan pendidikan gizi di awal penelitian disertai dengan pengiriman SMS sebagai reminder pesan gizi dan reminder minum tablet besi; dan kelompok kontrol (K) merupakan kelompok ibu hamil di Puskesmas Kayon yang menerima tablet besi tanpa mendapatkan intervensi apapun.

Pendidikan gizi adalah penyampaian informasi tentang anemia dan cara pencegahannya dengan metode penyuluhan kelompok menggunakan media power point, LCD, laptop, dan hand out. Penyuluhan dilaksanakan selama 30 menit sebanyak 1 kali di awal penelitian dan peneliti bertindak sebagai penyuluh. Penyuluhan diberikan secara bertahap pada subjek yang dibagi menjadi beberapa kelompok (10-15 orang), yaitu kelompok $\mathrm{P}_{1}$ yang terdiri dari 4 kelompok ibu hamil dan kelompok $\mathrm{P}_{2}$ yang terdiri dari 6 kelompok ibu hamil. 
Setelah intervensi pendidikan selesai, kelompok $P_{2}$ diintervensi dengan pesan gizi melalui SMS yaitu pesan singkat yang dikirim melalui media SMS dari handphone peneliti dengan isi pesan berupa materi pendidikan gizi dan anjuran minum tablet besi. Pengiriman SMS dilakukan 2 kali sehari (pagi dan malam). SMS yang dikirimkan pada pagi hari $(07.00-08.00$ WIB) berupa SMS reminder berisi tentang materi yang telah diberikan saat pendidikan gizi. Pengiriman SMS jenis ini dilakukan secara kontinyu selama 30 hari dengan materi yang berbeda setiap hari (30 SMS/ibu hamil selama 4 minggu). Sedangkan SMS yang dikirimkan pada malam hari (18.00-19.00 WIB) berupa SMS reminder berisi tentang motivasi dan anjuran minum tablet besi. Pengiriman SMS jenis ini dilakukan secara kontinyu selama 90 hari dengan siklus 7 hari (84 SMS/ibu hamil selama 12 minggu).

Pengetahuan ibu hamil tentang anemia dan cara pencegahannya diukur menggunakan kuesioner. Skor ditetapkan berdasarkan jawaban benar dan salah, jawaban benar diberi skor 1 dan salah diberi skor 0 . Skor 1 bernilai 5 poin sehingga total poin dari 20 pertanyaan yang diajukan adalah 100 poin. Perilaku adalah tindakan atau aktivitas ibu hamil dalam upaya pencegahan dan pengendalian anemia yang diukur menggunakan kuesioner. Skor ditetapkan berdasarkan jawaban yang dianggap paling baik (skor tertinggi $=2$ ) dan kurang baik (skor terendah $=0$ ) sehingga total skor dari 18 pertanyaan adalah 36 poin.

Data kepatuhan diperoleh dari hasil observasi di lapangan yaitu dengan menghitung sisa tablet besi yang masih ada serta keterangan dari form checklist yang berisi jadwal minum tablet besi. Sebagai data penguat juga dilakukan analisis kualitatif terhadap feses ibu hamil (stool test). Kepatuhan dibedakan menjadi 2 kategori, yaitu patuh jika jumlah tablet besi yang diminum selama 3 bulan adalah lebih dari atau sama dengan $90 \%$ ( $\geq 81$ butir) dan stool test positif (+) atau jika jumlah tablet besi yang diminum selama 3 bulan adalah kurang dari $90 \%$ (< 81 butir) namun stool test positif (+) sedangkan tidak patuh jika jumlah tablet besi yang diminum selama 3 bulan adalah kurang dari $90 \%(<$ 81 butir) dan stool test negatif (-) atau jika jumlah tablet besi yang diminum selama 3 bulan adalah lebih dari atau sama dengan $90 \%$ ( $\geq 81$ butir) tetapi hasil pemeriksaan stool test negatif (-).

Pengujian sampel darah yaitu kadar $\mathrm{Hb}$ dengan metode cyanmethemoglobin dan sampel feses dengan stool test dilaksanakan di Laboratorium Kesehatan Daerah Kota Palangka Raya dan Laboratorium Kimia Jurusan Gizi Poltekkes Kemenkes Palangka Raya. Pengambilan sampel darah vena sebanyak $1 \mathrm{cc}$ dilakukan oleh tenaga analis puskesmas setempat yang dilakukan setelah pendidikan gizi selesai dilaksanakan, sekaligus pembagian tablet besi (30 tablet) dari Puskesmas beserta form check list kepatuhan minum tablet besi. Kadar $\mathrm{Hb}$ dikategorikan berdasarkan cut off point anemia jika kadar Hb kurang dari $11 \mathrm{~g} / \mathrm{dl}$ dan normal jika kadar $\mathrm{Hb}$ lebih dari atau sama dengan $11 \mathrm{~g} / \mathrm{dl}(20)$.

Data dikumpulkan dengan menggunakan kuesioner yang telah diuji validitas dan reliabilitasnya yaitu kuesioner pengetahuan $(\alpha=0,87)$ dan perilaku $(\alpha=0,85)$. Evaluasi pengetahuan dan perilaku dilakukan sebelum (pre test) dan sesudah (post test) 1 bulan intervensi pendidikan gizi. Kepatuhan ibu hamil dievaluasi setiap bulan selama 3 bulan (90 hari) sedangkan kadar $\mathrm{Hb}$ ibu hamil dievaluasi sebelum dan sesudah 3 bulan intervensi.

Data diolah menggunakan program Stata 9.1 dengan melakukan uji paired $t$ test untuk melihat perbedaan mean sebelum dan sesudah diberi perlakuan pada masing-masing kelompok perlakuan, analisis of variance (ANOVA) untuk mengetahui perbedaan delta mean di antara 3 kelompok perlakuan, dan uji multiple comparasion test (Tukey test) untuk menentukan di mana letak perbedaan tersebut. Analisis regresi linier berganda dan analisis regresi logistik dilakukan untuk mengetahui pengaruh beberapa variabel bebas terhadap satu variabel terikat. Penelitian ini telah mendapatkan kelaikan etik (ethical clearance) dari Komisi Etik Penelitian Kedokteran dan Kesehatan Fakultas Kedokteran Universitas Gadjah Mada.

\section{HASIL}

\section{Karakteristik subjek penelitian}

Berdasarkan karakteristik umur subjek, umur termuda adalah 16 tahun dan tertua 42 tahun sedangkan kisaran umur paling banyak berada pada rentang 20-35 tahun $(72,73 \%)$ dan hanya $30,58 \%$ ibu dengan kehamilan risiko tinggi. Sebesar 39,67\% kehamilan subjek merupakan kehamilan pertama dan hanya $12,22 \%$ dengan paritas lebih besar atau sama dengan 3 . Sebagian besar tingkat pendidikan subjek $(55,37 \%)$ tergolong rendah dan tidak bekerja $(76,86 \%)$ dengan sebaran yang cukup merata pada setiap kelompok perlakuan. Jumlah terbanyak subjek yang bekerja terdapat pada kelompok kontrol yaitu sebesar 39,29\% (11 orang). Lebih dari 50\% tingkat pendidikan suami tergolong tinggi dan jumlah terbanyak terdapat pada kelompok kontrol $(47,62 \%)$. Sebaliknya, jumlah terbanyak suami dengan tingkat pendidikan rendah terdapat pada kelompok perlakuan pendidikan gizi disertai SMS (46,55\%). Sebaran tingkat pendidikan suami pada masing-masing kelompok perlakuan berbeda bermakna $(p<0,05)$ (Tabel 1).

Pendapatan total keluarga diperoleh dari penggabungan pendapatan suami dan pendapatan istri (ibu hamil yang menjadi subjek dalam penelitian ini). Kisaran pendapatan total dari seluruh subjek penelitian ini sebesar Rp 250.000 sampai dengan lebih dari Rp 2.000.000. Sebagian besar $(73,55 \%)$ pendapatan total keluarga subjek penelitian dikategorikan di atas upah minimum regional (UMR). Sebagai gambaran awal kondisi 
Tabel 1. Karakteristik subjek penelitian dan keluarganya

\begin{tabular}{|c|c|c|c|c|}
\hline \multirow{2}{*}{ Variabel } & \multicolumn{3}{|c|}{ Kelompok perlakuan $(n, \%)$} & \multirow[b]{2}{*}{$\mathbf{p}$} \\
\hline & $\mathbf{P}_{1}$ & $\mathbf{P}_{2}$ & $\mathrm{~K}$ & \\
\hline \multicolumn{5}{|l|}{ Umur ibu } \\
\hline Berisiko & $12(29,3)$ & $9(22,5)$ & $16(40,0)$ & \multirow[t]{2}{*}{0,230} \\
\hline Tidak berisiko & $29(70,7)$ & $31(77,5)$ & $24(60,0)$ & \\
\hline \multicolumn{5}{|l|}{ Paritas } \\
\hline 0 & $18(43,9)$ & $14(35,0)$ & $16(40,0)$ & \multirow[t]{4}{*}{0,528} \\
\hline 1 & $11(26,8)$ & $14(35,0)$ & $12(30,0)$ & \\
\hline 2 & $9(22,0)$ & $7(17,5)$ & $4(10,0)$ & \\
\hline$\geq 3$ & $3(7,3)$ & $5(12,5)$ & $8(20,0)$ & \\
\hline \multicolumn{5}{|l|}{ Pendidikan ibu } \\
\hline Tinggi & $20(48,8)$ & $13(32,5)$ & $21(52,5)$ & \multirow[t]{2}{*}{0,160} \\
\hline Rendah & $21(51,2)$ & $27(67,5)$ & $19(47,5)$ & \\
\hline \multicolumn{5}{|l|}{ Pekerjaan ibu } \\
\hline Bekerja & $8(19,5)$ & $9(22,5)$ & $11(27,5)$ & \multirow[t]{2}{*}{0,691} \\
\hline Tidak bekerja & $23(80,5)$ & $31(77,5)$ & $29(72,5)$ & \\
\hline \multicolumn{5}{|l|}{ Pendidikan suami } \\
\hline Tinggi & $20(48,8)$ & $13(32,5)$ & $30(75,0)$ & \multirow[t]{2}{*}{$0,001^{*}$} \\
\hline Rendah & $21(51,2)$ & $27(67,5)$ & $10(25,0)$ & \\
\hline \multicolumn{5}{|l|}{ Pendapatan total } \\
\hline$<$ UMR & $13(31,7)$ & $9(22,5)$ & $10(25,0)$ & \multirow[t]{2}{*}{0,623} \\
\hline$\geq$ UMR & $28(68,3)$ & $21(77,5)$ & $30(75,0)$ & \\
\hline \multicolumn{5}{|l|}{ Status anemia } \\
\hline Anemia & $7(17,7)$ & $14(35,0)$ & $15(37,5)$ & \multirow[t]{2}{*}{0,089} \\
\hline Tidak anemia & $34(82,9)$ & $26(65,0)$ & $25(62,5)$ & \\
\hline
\end{tabular}

Keterangan:

$\mathrm{P}_{1}=$ kelompok perlakuan pendidikan gizi;

$\mathrm{P}_{2}=$ kelompok perlakuan pendidikan gizi dan pesan gizi melalui SMS;

$\mathrm{K}^{2}=$ kelompok kontrol;

Umur ibu berisiko $=<20$ tahun dan $>35$ tahun;

Tingkat pendidikan rendah = pendidikan terakhir $\leq$ Sekolah Menengah

Pertama (SMP)/sederajat;

UMR = upah minimum regional (Provinsi Kalimantan Tengah

Rp 765.868,-) (18);

Anemia $=\mathrm{Hb}<11 \mathrm{~g} / \mathrm{dl}$, tidak anemia $=\mathrm{Hb} \geq 11 \mathrm{~g} / \mathrm{dl}$

* bermakna $(p<0,05)$

klinis ibu hamil yang menjadi subjek dalam penelitian ini, dilakukan juga pengukuran kadar $\mathrm{Hb}$ awal. Subjek dengan anemia sebanyak $29,75 \%$ (36 dari 121 sampel) dengan sebaran $41,7 \%$ pada kelompok kontrol, $38,9 \%$ pada kelompok perlakuan pendidikan gizi disertai SMS, dan $19,4 \%$ pada kelompok perlakuan pendidikan gizi saja.

\section{Efek perlakuan terhadap pengetahuan ibu hamil}

Sebagian besar subjek telah mengetahui istilah anemia $(87,6 \%)$ dari majalah atau buku dan poster-poster $(35,5 \%)$ dan mengenal istilah kurang darah dari petugas kesehatan (42,5\%). Sementara itu, tempat mendapatkan tablet tambah darah sebagian besar di puskesmas (55\%) dan hampir seluruh subjek mengetahui bahwa warna tablet besi adalah merah (95\%).

Rerata skor pengetahuan sebelum intervensi di antara ketiga kelompok perlakuan tidak berbeda bermakna $(p>0,05)$ dengan rerata nilai pengetahuan sebesar 60 . Perbedaan rerata skor pengetahuan terlihat setelah kelompok perlakuan mendapatkan intervensi $(p<0,05)$ kecuali pada kelompok kontrol. Delta skor pengetahuan yang terbesar diperoleh kelompok subjek dengan intervensi pendidikan gizi disertai SMS kemudian diikuti oleh kelompok subjek yang mendapat pendidikan gizi saja dan kelompok kontrol (Tabel 2). Pengetahuan subjek yang mendapat pendidikan gizi disertai SMS berbeda secara bermakna $(p<0,05)$ dibandingkan dengan pengetahuan subjek yang mendapat pendidikan gizi saja dan kelompok kontrol.

Hasil analisis multivariat menunjukkan bahwa pendidikan gizi disertai SMS berpengaruh terhadap peningkatan pengetahuan subjek sebesar 51,43 poin atau 18 poin lebih tinggi dibandingkan kontrol. Sementara itu, jika diintervensi dengan pendidikan saja hanya mampu meningkatkan pengetahuan subjek sebesar 39,11 poin atau 6 poin lebih tinggi dibanding kontrol. Selain itu, peningkatan pengetahuan juga dipengaruhi oleh skor awal pengetahuan.

\section{Efek perlakuan terhadap perilaku ibu hamil}

Rerata skor perilaku sebelum intervensi tidak jauh berbeda di antara ketiga kelompok perlakuan. Hasil analisis menunjukkan perbedaan bermakna skor perilaku sebelum dan sesudah intervensi pada masing-masing kelompok perlakuan $(p<0,05)$. Perubahan terbesar skor perilaku terdapat pada kelompok subjek yang mendapat pendidikan gizi disertai SMS (Tabel 3). Perilaku subjek yang mendapat pendidikan gizi disertai SMS berbeda secara bermakna $(p<0,05)$ dibandingkan dengan perilaku subjek yang mendapat pendidikan gizi saja dan kelompok kontrol.

Hasil analisis multivariat menunjukkan bahwa peningkatan skor perilaku subjek sebelum dan sesudah intervensi dipengaruhi oleh perlakuan dan skor awal perilaku. Pendidikan gizi disertai SMS berpengaruh terhadap peningkatan perilaku subjek sebesar 25,32 poin atau 4,07 poin lebih tinggi dibandingkan kontrol sedangkan pada intervensi pendidikan gizi saja hanya mampu meningkatkan skor perilaku sebesar 22,8 poin atau 2 poin lebih tinggi dibandingkan kontrol.

\section{Efek perlakuan terhadap kepatuhan ibu hamil minum tablet besi}

Nilai tengah kepatuhan minum tablet besi pada kelompok pendidikan gizi saja dan kontrol hanya $63 \%$ sedangkan pada kelompok perlakuan pendidikan gizi disertai SMS mencapai $89,4 \%$ atau $26 \%$ lebih tinggi dibandingkan dengan kontrol $(p<0,05)$. Hal ini menunjukkan bahwa peran SMS dalam meningkatkan kepatuhan subjek cukup besar. Berdasarkan distribusi kepatuhan, ditemukan perbedaan yang bermakna $(p<0,05)$ di antara ketiga kelompok perlakuan. Hasil penelitian menunjukkan kelompok yang diberi perlakuan pendidikan gizi dan SMS lebih banyak yang patuh $(50 \%)$ dibandingkan kelompok pendidikan saja 
Tabel 2. Perbedaan skor pengetahuan sebelum dan sesudah intervensi

\begin{tabular}{|c|c|c|c|c|c|}
\hline \multirow{2}{*}{ Perlakuan } & \multicolumn{2}{|c|}{ Rerata ( $\pm S D)$} & \multirow{2}{*}{$\Delta$} & \multirow{2}{*}{$95 \% \mathrm{Cl}$} & \multirow{2}{*}{$p$} \\
\hline & Sebelum & Sesudah & & & \\
\hline Pendidikan gizi & $60,85 \pm 12,89$ & $69,39 \pm 16,13$ & 8,54 & $4,30-12,77$ & $0,000^{*}$ \\
\hline Pendidikan gizi + SMS & $63,13 \pm 15,51$ & $82,25 \pm 11,71$ & 19,12 & $14,56-23,68$ & $0,000^{*}$ \\
\hline Kontrol & $60,38 \pm 14,38$ & $62,75 \pm 12,03$ & 2,37 & $-1,49-6,24$ & 0,111 \\
\hline
\end{tabular}

Keterangan: $\quad \Delta=$ delta perubahan; ${ }^{*}$ paired $t$ test, bermakna $(p<0,05)$

Tabel 3. Perbedaan skor perilaku sebelum dan sesudah intervensi

\begin{tabular}{|c|c|c|c|c|c|}
\hline \multirow{2}{*}{ Perlakuan } & \multicolumn{2}{|c|}{ Rerata ( $\pm S D$ ) } & \multirow{2}{*}{$\Delta$} & \multirow{2}{*}{$95 \% \mathrm{Cl}$} & \multirow{2}{*}{$\mathbf{p}$} \\
\hline & Sebelum & Sesudah & & & \\
\hline Pendidikan gizi & $27,51 \pm 4,36$ & $29,93 \pm 3,19$ & 2,42 & $1,24-3,59$ & $0,000^{*}$ \\
\hline Pendidikan gizi + SMS & $26,96 \pm 4,91$ & $32,25 \pm 2,69$ & 5,29 & $3,66-6,89$ & $0,000^{*}$ \\
\hline Kontrol & $26,22 \pm 4,42$ & $27,68 \pm 2,95$ & 1,46 & $0,09-2,81$ & $0,019^{*}$ \\
\hline
\end{tabular}

Keterangan : $\Delta=$ delta perubahan; * paired t test, bermakna $(p<0,05)$

Tabel 4. Distribusi kepatuhan ibu hamil minum tablet besi

\begin{tabular}{|c|c|c|c|c|}
\hline \multirow{2}{*}{ Perlakuan } & \multicolumn{2}{|c|}{ Kepatuhan (n,\%) } & \multirow{2}{*}{$X^{2}$} & \multirow{2}{*}{ p } \\
\hline & Patuh & Tidak patuh & & \\
\hline Pendidikan gizi & $11(26,8 \%)$ & $30(73,2 \%)$ & & \\
\hline Pendidikan gizi + SMS & $20(50,0 \%)$ & $20(50,0 \%)$ & 10,41 & $0,005^{*}$ \\
\hline Kontrol & $7(17,5 \%)$ & $33(82,5 \%)$ & & \\
\hline
\end{tabular}

Keterangan : * bermakna $(p<0,05)$

Tabel 5. Perbedaan kadar hemoglobin sebelum dan sesudah perlakuan

\begin{tabular}{|c|c|c|c|c|c|}
\hline \multirow{2}{*}{ Perlakuan } & \multicolumn{2}{|c|}{ Rerata kadar Hb (g/dl) } & \multirow{2}{*}{$\Delta$} & \multirow{2}{*}{$95 \% \mathrm{Cl}$} & \multirow[b]{2}{*}{$\mathbf{p}$} \\
\hline & Sebelum & Sesudah & & & \\
\hline Pendidikan gizi & $11,76 \pm 0,8$ & $11,64 \pm 1,0$ & $-0,12$ & $-0,46-0,23$ & 0,744 \\
\hline Pendidikan gizi + SMS & $11,48 \pm 1,1$ & $11,98 \pm 1,1$ & 0,50 & $0,12-0,87$ & $0,005^{*}$ \\
\hline Kontrol & $11,24 \pm 1,2$ & $11,10 \pm 1,0$ & $-0,06$ & $-0,33-0,14$ & 0,782 \\
\hline
\end{tabular}

Keterangan : $\Delta=$ delta perubahan; * paired $t$ test, bermakna $(p<0,05)$

$(26,8 \%)$ dan kontrol $(17,5 \%)(p<0,05)$ (Tabel 4). Demikian pula dengan hasil analisis multivariat yang menunjukkan bahwa kepatuhan subjek minum tablet besi dipengaruhi oleh intervensi pendidikan gizi disertai SMS $(p<0,05)$. Jumlah tablet besi yang habis diminum 11 butir lebih banyak pada kelompok subjek yang mendapat intervensi pendidikan gizi disertai SMS dibandingkan kontrol sehingga dapat disimpulkan bahwa ibu hamil yang mendapat intervensi pendidikan gizi disertai SMS lebih patuh dibandingkan kontrol $(p<0,05)$. Subjek yang mendapat pendidikan gizi disertai SMS memiliki kemungkinan 4 kali lebih patuh dibandingkan subjek pada kelompok kontrol $(\mathrm{OR}=3,79$; 95\% Cl:1,14-12,61; $p=0,03)$.

Pada kelompok kontrol, sebagian besar alasan ketidakpatuhan subjek dalam mengonsumsi tablet besi adalah lupa $(60,8 \%)$ dan efek samping mual $(35 \%)$. Sebaliknya, pada kelompok yang diberi pendidikan gizi disertai SMS hanya $21 \%$ karena faktor lupa dan sebesar 53\% karena efek samping mual. Pendidikan gizi saja ternyata belum mampu meningkatkan kepatuhan atau dengan kata lain ketidakpatuhan ibu hamil bukan disebabkan ketidaktahuan tetapi karena lupa sehingga sangat dibutuhkan reminder seperti SMS.

\section{Efek perlakuan terhadap kadar hemoglobin}

Rerata kadar $\mathrm{Hb}$ sebelum dan sesudah intervensi cenderung menurun tetapi masih dalam batas normal (11 $\mathrm{g} / \mathrm{dl})$, hanya pada kelompok perlakuan dengan intervensi pendidikan gizi disertai SMS yang mengalami peningkatan bermakna sebesar 0,5 g/dl $(p<0,05)$ (Tabel 5). Artinya, pendidikan gizi saja tidaklah cukup untuk meningkatkan kadar $\mathrm{Hb}$ karena perubahannya tidak bermakna dibandingkan dengan kontrol $(p>0,05)$. Oleh karena itu, dapat disimpulkan bahwa peningkatan kadar $\mathrm{Hb}$ subjek kemungkinan terjadi apabila subjek dibekali dengan pendidikan gizi disertai SMS.

Namun, hasil analisis multivariat menunjukkan bahwa perubahan kadar $\mathrm{Hb}$ tidak dipengaruhi oleh perlakuan melainkan kepatuhan subjek minum tablet besi $(\mathrm{p}<0,05)$ dan kadar $\mathrm{Hb}$ awal. Subjek yang patuh pada 


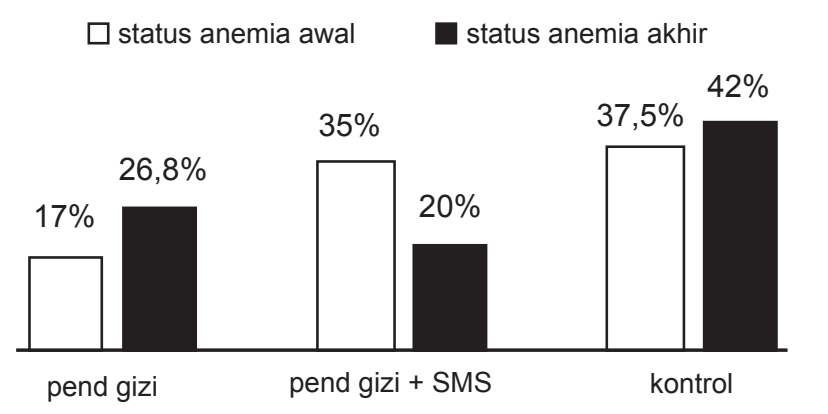

Gambar 2. Prevalensi anemia pada masing-masing kelompok perlakuan

kelompok perlakuan akan mengalami peningkatan kadar $\mathrm{Hb}$ sebesar 1,6 poin lebih tinggi dibandingkan subjek yang patuh pada kelompok kontrol. Hal ini menunjukkan bahwa perubahan kadar $\mathrm{Hb}$ sebelum dan sesudah intervensi bukanlah pengaruh langsung dari intervensi yang diberikan tetapi merupakan outcome dari kepatuhan.

Lebih lanjut, hasil analisis multivariat menunjukkan bahwa outcome delta perubahan kadar $\mathrm{Hb}$ dipengaruhi oleh kepatuhan dan kadar $\mathrm{Hb}$ awal. Pada subjek yang mempunyai kadar $\mathrm{Hb}$ awal kurang dari $11 \mathrm{~g} / \mathrm{dl}$, terjadi peningkatan kadar $\mathrm{Hb}$ yang bermakna $(p<0,05)$ dalam pola dose-response atau kadar $\mathrm{Hb}$ meningkat sesuai dengan peningkatan kepatuhan. Berbeda halnya dengan subjek yang pada awalnya memiliki kadar $\mathrm{Hb}$ lebih dari $11 \mathrm{~g} / \mathrm{dl}$, meskipun pola dose-response juga terjadi tetapi kadar $\mathrm{Hb}$ cenderung menurun hingga $0,9 \mathrm{~g} / \mathrm{dl}$ pada tingkat kepatuhan yang rendah $(<50 \%)$. Peningkatan kadar $\mathrm{Hb}$ bermakna hingga $1,3 \mathrm{~g} / \mathrm{dl}(\mathrm{p}<0,05)$ apabila kepatuhan ibu hamil minum tablet besi mencapai lebih dari $90 \%$.

Peningkatan kadar $\mathrm{Hb}$ yang bermakna ini erat hubungannya dengan status anemia sesudah intervensi. Distribusi frekuensi kadar $\mathrm{Hb}$ (dikotomus) memberikan gambaran prevalensi anemia di masing-masing kelompok perlakuan (Gambar 2). Penurunan prevalensi anemia terjadi hingga $15 \%$ pada kelompok perlakuan pendidikan gizi disertai SMS. Hal ini berkaitan dengan kadar $\mathrm{Hb}$ awal ibu hamil $(<11 \mathrm{~g} / \mathrm{dl})$ serta tingkat kepatuhan yang cukup tinggi (50\%). Seperti dijelaskan sebelumnya bahwa peningkatan kadar $\mathrm{Hb}$ merupakan outcome dari kadar $\mathrm{Hb}$ awal dan kepatuhan, maka meskipun persentase kepatuhan kelompok pendidikan gizi saja $(26,8 \%)$ lebih besar dari kepatuhan pada kelompok kontrol (17,5\%), tetapi terlihat peningkatan prevalensi anemia lebih besar pada kelompok pendidikan gizi saja dibandingkan kelompok kontrol (Gambar 2). Hal ini terjadi karena nilai median kepatuhan dari kedua kelompok ini sama yaitu $63,3 \%$ (<90\%) sehingga cenderung menyebabkan penurunan kadar $\mathrm{Hb}$. Sebaliknya, nilai median kepatuhan dari kelompok pendidikan gizi disertai SMS sebesar $89,4 \%$ (mendekati 90\%) sehingga memungkinkan terjadinya kenaikan kadar $\mathrm{Hb}$ ibu hamil.

\section{BAHASAN}

Hasil penelitian menunjukkan bahwa intervensi pendidikan gizi disertai SMS mampu meningkatkan pengetahuan dan perilaku subjek terkait masalah anemia dan cara pencegahannya. Peningkatan skor pengetahuan dan perilaku merupakan pengaruh dari intervensi pendidikan gizi dengan kombinasi media penyampaian pesan (SMS). Hal ini dapat dijelaskan dengan teori Precede-Proceed bahwa peningkatan skor pengetahuan dan perilaku merupakan faktor predisposisi (predisposing factor) dari perubahan perilaku yang akan terjadi (21). Indikator perubahan perilaku dalam penelitian ini adalah tingkat kepatuhan dengan outcome kadar $\mathrm{Hb}$.

Hasil penelitian ini juga menunjukkan bahwa pendidikan gizi disertai SMS dapat meningkatkan kepatuhan ibu hamil dalam mengonsumsi tablet besi. Faktor lain yang tidak bisa diabaikan adalah faktor penguat dan faktor pemungkin. Faktor pemungkin (enabling factor) dalam penelitian ini berupa sarana kesehatan yang ada di Kota Palangka Raya. Sarana kesehatan seperti puskesmas, puskesmas pembantu (pustu), pondok bersalin desa (polindes), pos kesehatan desa (poskesdes), dan rumah sakit berjumlah 74 buah, sarana upaya kesehatan bersumberdaya masyarakat (posyandu) berjumlah 125 buah, dan sarana pelayanan kesehatan swasta (rumah bersalin, klinik, balai pengobatan, apotik, laboratorium swasta, dII) berjumlah 163 buah, serta sarana kesehatan lainnya seperti sarana kesehatan alternatif berjumlah 6 buah yang telah terdaftar dan dimanfaatkan masyarakat (18). Di samping itu, faktor penguat (reinforcing factor) yang mungkin dapat teramati dalam penelitian ini adalah keluarga khususnya suami. Suami yang bertindak sebagai supervisor mampu meningkatkan kepatuhan ibu hamil dalam minum tablet besi hingga $16 \%$ lebih tinggi. Selain suami, petugas kesehatan terutama bidan juga mempunyai peranan yang sangat penting dalam proses perubahan perilaku ibu hamil khususnya kepatuhan minum tablet besi (4).

Penyuluhan dan pemberian tablet saja tidak cukup untuk mencapai keberhasilan program (22). Hasil penelitian ini menunjukkan bahwa intervensi pendidikan gizi saja kurang mampu meningkatkan pengetahuan subjek. Pendidikan gizi saja mampu meningkatkan skor pengetahuan dan perilaku subjek, tetapi nilainya lebih kecil jika dibandingkan dengan peningkatan skor pengetahuan pada kelompok yang mendapat intervensi pendidikan gizi disertai SMS. Kemampuan seseorang dalam menangkap informasi yang diberikan berbeda-beda menurut penggunaan panca indera. Apabila hanya dengan indera pendengaran maka informasi yang ditangkap hanya mencapai $15 \%$, jika mendengar dan melihat mencapai $35-55 \%$, namun jika mendengar, melihat, mengerjakan sendiri, dan berpikir dapat mencapai 80 - 
$90 \%$ (23). Short message service sebagai media dalam menyampaikan informasi diberikan secara kontinyu dan berkesinambungan sehingga berpengaruh terhadap pengetahuan dan perilaku subjek penelitian. Peran media sangat penting dalam mencapai tujuan promosi kesehatan terutama dalam meningkatkan kesadaran kesehatan, meningkatkan pengetahuan kesehatan, pemberdayaan diri sendiri, mempengaruhi perubahan sikap, pengambilan keputusan, dan perubahan perilaku. Media pada umumnya efektif untuk membangkitkan respon emosional yang mungkin menuju pada tindakan yang nyata (24).

Hasil penelitian di Kartasura menyimpulkan bahwa pendidikan kesehatan dapat meningkatkan pengetahuan ibu hamil dalam mengatasi keluhan selama hamil sebesar 13,3\% (25). Penelitian Iain di India juga menyatakan bahwa pendidikan kesehatan secara bermakna dapat meningkatkan pengetahuan dan sikap ibu dalam mencegah anemia tetapi tidak bermakna dalam merubah perilaku konsumsi tablet besi dan konsumsi makanan kaya akan zat besi (26). Demikian pula hasil penelitian di Surabaya yang menunjukkan bahwa media SMS efektif dalam meningkatkan pengetahuan remaja sebesar 38,9\% namun kurang efektif dalam mempengaruhi sikap terkait aborsi $(6,6 \%)(27)$.

Kepatuhan minum tablet besi pada kelompok perlakuan pendidikan gizi disertai SMS mencapai $89,4 \%$ atau $26 \%$ lebih tinggi dibandingkan dengan kelompok pendidikan gizi saja dan kontrol. Hal ini terjadi karena adanya reminder (SMS) yang selalu dikirimkan secara berkelanjutan setiap hari untuk mengingatkan ibu hamil minum tablet besi. SMS dalam bentuk pesan motivasi atau anjuran ini berperan sebagai pengingat atau reminder dalam mengurangi faktor lupa yang selama ini menjadi alasan utama ketidakpatuhan. Banyak hasil penelitian yang melaporkan bahwa lupa dalam mengonsumsi tablet besi merupakan faktor penting yang dapat menurunkan kepatuhan ibu hamil minum tablet besi $(4,8,11-13)$.

SMS yang dikirimkan ke handphone subjek penelitian pada kelompok perlakuan pendidikan gizi disertai SMS mampu meminimalisasi faktor lupa hingga 40\% dan dapat meningkatkan kepatuhan subjek mengonsumsi tablet besi hingga 32,5\% ( $p<0,05)$. Hal ini menunjukkan bahwa intervensi pendidikan gizi saja belum mampu mengurangi ketidakpatuhan yang disebabkan oleh faktor lupa sehingga upaya yang tepat untuk meningkatkan kepatuhan ibu hamil minum tablet besi adalah dengan cara mengingatkannya melalui media (SMS). Peneliti lain di Amerika Serikat juga melaporkan peran media dalam meningkatkan kepatuhan (7).

Alasan lain yang juga menjadi penyebab rendahnya kepatuhan pada subjek penelititan ini adalah adanya efek samping tablet besi. Hal ini didukung oleh hasil penelitian di Iran dan Malawi yang menyatakan bahwa sebagian subjek
$(30,3 \%)$ mengalami efek samping setelah mengonsumsi tablet besi dan sebesar 34,9\% subjek menghentikan konsumsi tablet besi karena mual $(28,29)$. Analisis lebih lanjut pada kelompok kontrol menunjukkan bahwa efek samping yang sering muncul adalah mual (35\%), rasa tidak enak di perut (21\%), susah buang air besar (17\%), dan perut terasa kejang (9\%). Sebagian besar (53\%) ketidakpatuhan subjek pada kelompok pendidikan gizi disertai SMS disebabkan oleh adanya efek samping tersebut. Hal inilah yang menjadi penyebab besarnya jumlah subjek yang tidak patuh (50\%) pada kelompok pendidikan gizi disertai SMS. Pada beberapa orang, pemberian tablet besi dapat menimbulkan gejala seperti mual, nyeri di daerah lambung, muntah, dan kadangkadang terjadi diare atau sulit buang air besar. Dianjurkan konsumsi tablet besi dengan air putih setelah makan pada malam hari untuk mencegah timbulnya gejala tersebut (30).

Rerata kadar Hb pada kelompok perlakuan pendidikan gizi disertai SMS mengalami peningkatan bermakna. Berbeda dengan rerata kadar $\mathrm{Hb}$ subjek pada kelompok pendidikan gizi saja dan kontrol yang cenderung menurun meskipun masih dalam batas normal $(11 \mathrm{~g} / \mathrm{dl})$. Penurunan ini disebabkan oleh tingginya ketidakpatuhan subjek dalam mengonsumsi tablet besi (73\% dan 82,5\%). Secara normal, tanpa ada suplementasi tablet besi, kadar $\mathrm{Hb}$ ibu hamil cenderung menurun dengan semakin bertambahnya usia kehamilan (31). Sehingga dapat disimpulkan bahwa ibu hamil yang tidak patuh dalam meminum tablet besi, kemungkinan untuk menderita anemia semakin besar karena kebutuhan zat besi semakin meningkat seiring dengan meningkatnya usia kehamilan.

Hail analisis multivariat menunjukkan bahwa jenis perlakuan tidak berpengaruh bermakna terhadap perubahan kadar $\mathrm{Hb}$, melainkan berpengaruh terhadap kepatuhan. Intervensi pendidikan gizi disertai SMS terbukti mampu meningkatkan kepatuhan subjek minum tablet besi dan peningkatan kadar $\mathrm{Hb}$ secara bermakna dipengaruhi oleh kepatuhan subjek minum tablet besi. Kenaikan kadar $\mathrm{Hb}$ akan bermakna pada subjek dengan kadar $\mathrm{Hb}$ awal kurang dari $11 \mathrm{~g} / \mathrm{dl}$ dan tergantung tingkat kepatuhan. Dengan demikian, peningkatan kadar $\mathrm{Hb}$ semakin besar dengan semakin meningkatnya kepatuhan (dose response). Peneliti lain juga menemukan bahwa kenaikan kadar $\mathrm{Hb}$ dipengaruhi oleh kadar $\mathrm{Hb}$ awal (4). Pada kelompok ibu hamil dengan kadar $\mathrm{Hb}$ awal kurang dari atau sama dengan $11 \mathrm{~g} / \mathrm{dl}$, kadar $\mathrm{Hb}$ cenderung menurun apabila tingkat kepatuhan konsumsi tablet besi kurang dari $90 \%$. Rerata kadar $\mathrm{Hb}$ pada trisemester I adalah $12,3 \mathrm{~g} / 100 \mathrm{ml}, 11,3 \mathrm{~g} / 100 \mathrm{ml}$ pada trisemester II, dan 10,8 $\mathrm{g} / 100 \mathrm{ml}$ pada trisemester III. Terjadinya penurunan kadar $\mathrm{Hb}$ disebabkan oleh pengenceran darah seiring dengan meningkatnya umur kehamilan sehingga frekuensi anemia dalam kehamilan pun meningkat pula (31). Kadar $\mathrm{Hb}$ 
kembali meningkat disaat kepatuhan mencapai lebih dari atau sama dengan $90 \%$. Artinya, ibu hamil yang pada awal kehamilannya memiliki kadar $\mathrm{Hb}$ lebih dari $11 \mathrm{~g} / \mathrm{dl}$ (normal) tetap memiliki kecenderungan mengalami anemia apabila tidak patuh minum tablet besi terutama jika didukung dengan kurangnya asupan makanan sumber zat besi.

Kepatuhan minum tablet besi di bawah $70 \%$ bagi ibu hamil dengan kadar $\mathrm{Hb}$ awal kurang dari $11 \mathrm{~g} / \mathrm{dl}$ dan kepatuhan kurang dari $90 \%$ bagi ibu hamil dengan kadar $\mathrm{Hb}$ awal lebih dari atau sama dengan $11 \mathrm{~g} / \mathrm{dl}$ kurang mampu meningkatkan kadar $\mathrm{Hb}$ secara bermakna selama masa kehamilan. Defisit zat besi dapat terjadi karena asupan zat besi ibu hamil (baik dari asupan makanan maupun dari suplementasi) belum memenuhi kebutuhan minimal zat besi yang seharusnya terabsorbsi selama masa kehamilan (4).

Penelitian ini menunjukkan bahwa subjek pada kelompok perlakuan pendidikan gizi disertai SMS memiliki kemungkinan 4 kali lebih patuh dengan peningkatan kepatuhan hingga 32,5\% dibandingkan kontrol. Oleh karena itu, salah satu upaya untuk meningkatkan kepatuhan ibu hamil minum tablet besi dapat dilakukan dengan cara mengingatkannya melalui SMS. Apabila kepatuhan mencapai lebih dari atau sama dengan $70 \%$ akan dapat meningkatkan kadar $\mathrm{Hb}$ sebesar 0,5 - 1,3 g/ dl pada ibu hamil dengan catatan kadar $\mathrm{Hb}$ awal kurang dari $11 \mathrm{~g} / \mathrm{dl}$ sedangkan jika kadar $\mathrm{Hb}$ awal lebih dari atau sama dengan $11 \mathrm{~g} / \mathrm{dl}$, seorang ibu hamil harus dapat meningkatkan kepatuhan hingga lebih dari atau sama dengan $90 \%$ untuk dapat meningkatkan kadar $\mathrm{Hb}$ hingga 1,3 g/dl. Informasi ini sangat penting bagi program pencegahan dan penanggulangan anemia, seperti jumlah kasus anemia dalam penelitian ini yang menurun hingga $15 \%$ pada populasi ibu hamil yang mendapat intervensi pendidikan gizi disertai SMS. Dengan demikian, dianjurkan untuk memberikan intervensi pendidikan gizi disertai pengiriman SMS sebagai salah satu upaya mencegah dan menurunkan prevalensi anemia.

\section{SIMPULAN DAN SARAN}

Peningkatan pengetahuan dan perilaku ibu hamil pada kelompok pendidikan gizi disertai SMS lebih tinggi daripada kelompok pendidikan gizi saja dan kontrol. Demikian juga dengan kepatuhan minum tablet besi dan peningkatan kadar $\mathrm{Hb}$ ibu hamil pada kelompok pendidikan gizi disertai SMS lebih tinggi dibandingkan kelompok pendidikan gizi saja dan kontrol.

Pada populasi dengan handphone yang dimiliki dan digunakan oleh mayoritas ibu hamil, SMS bisa menjadi media untuk meningkatkan kepatuhan yang berdampak pada peningkatan kadar $\mathrm{Hb}$. Sesuai dengan tujuan dari promosi kesehatan dalam penyampaian informasi kesehatan, SMS bisa digunakan sebagai reminder dan penguat terhadap pengetahuan yang sudah ada.

\section{RUJUKAN}

1. Vijayaraghavan K. Anemia karena defisiensi zat besi gizi. Dalam: Gibney MJ, Margetts BM, Kearney JM, Arab L. Gizi kesehatan masyarakat (public health nutrition). Jakarta: EGC; 2009.

2. Departemen Kesehatan RI. Laporan nasional riskesdas tahun 2007. Jakarta: Depkes RI; 2008.

3. McLean E, Egli I, Benoist B, Wojdyla D, Cogswell M. Worldwide prevalence of anemia in preschool aged children, pregnant women and non-pregnant women of reproductive age. Dalam: Kraemer K, Zimmermann MB. Nutritional anemia. Switzerland: Sight and Life Press; 2007.

4. Hadi H. Meningkatkan kepatuhan minum tablet besi ibu hamil: pentingnya peranan suami. Berita Kedokteran Masyarakat 2001;XVII(2):51-61.

5. Triratnawati A. Upaya peningkatan kepatuhan ibu hamil dalam mengkonsumsi pil tambah darah. Jurnal Epidemiologi Indoneisa 1998;2(3):43-9.

6. Schulthink W, van der Ree M, Matulessi P, Gross R. Low compliance with an iron supplementation program: a study among pregnant women in Jakarta, Indonesia. Am J Clin Nutr 1993;57(2):135-9.

7. Galloway R, McGuire J. Determinants of compliance with iron suplementation: supplies, side effects, or psychology? Soc Sci Med 1994;39(3):381-90.

8. Winichagoon P. Prevention and control of anemia: Thailand experiences. J Nutr 2002;132(4):862S-6S.

9. Davidsson L, Penelope N. Efficacy and effectiveness of intervensions to control iron deficiency and iron deficiency anemia. USA: INACG; 2004.

10. Seck BC, Jackson RT. Determinants of compliance with iron supplementation among pregnant women in Senegal. Public Health Nutr 2007;11(6):596-605.

11. Vongvichit $P$, Isaranurug $S$, Nanthamongkolchai $S$, Voramongkol N. Compliance of pregnant women regarding iron supplementation in Vientiane Municipality, Lao P.D.R. Journal of Public Health and Development 2003;11(1):41-52.

12. Jamil MD, Hadi $H$, Toto $S$. Pengaruh pendidikan gizi suami terhadap kepatuhan minum tablet besi dan kadar haemoglobin pada ibu hamil di Kabupaten Bantul, Yogyakarta. Jurnal Teknologi Kesehatan 2005;1(1):22-34.

13. Widagdo D, Hadi H, Lestariana W. Pengaruh suplementasi tablet Fe dengan supervisi suami pada ibu hamil terhadap umur kehamilan di Kabupaten Bantul. Jurnal Gizi Klinik Indonesia 2005;2(1):22-7.

14. Simons-Morton BG, Green WH, Gottlieb NH. Introduction to health education and health promotion. USA: Waveland Press,Inc; 1995. 
15. Rodgers A, Corbett T, Bramley D, Riddell T, Wills M, Lin R-B, Jones M. Do u smoke after txt? Result of a randomized trial of smoking cessation using mobile phone text messaging. Tob Control 2005;14(4):25561.

16. Leong CK, Chen WS, Leong KW, Matura I, Mimi O, Sheikh MA, Zailinawati AH, Ng JC, Phua KL, Teng CL. The use of text messaging to improve attendance in primary care: a randomized controlled trial. Fam Pract 2006;23(6):699-705.

17. Koshy E, Car J, Majeed A. Effectiveness of mobilephone short message service (SMS) reminders for ophthalmology outpatient appointments: observational study. BMC Ophthalmol 2008;8:9.

18. Dinas Kesehatan Kota Palangka Raya. Profil kesehatan Kota Palangka Raya tahun 2008. Palangka Raya; Dinkes Kota Palangka Raya; 2009.

19. Lemeshow S, Hosmer Jr DW, Klar J, Lwanga SK. Besar sampel dalam penelitian kesehatan. Pramono D. 1997 (Alih bahasa). Yogyakarta: UGM Press; 1997.

20. WHO. Iron deficiency anaemia assessment, prevention and control, a guide for programme managers. Geneva, Switzerland: World Health Organization; 2011.

21. Dignan MB, Carr PA. Program planning for health education and promotion. USA: Lea and Febiger; 1992.

22. De Maeyer DM. Pencegahan dan pengawasan anemia defisiensi besi. Arisman MB (Alih bahasa). Jakarta: Widya Medika; 1995.
23. Suhardjo. Berbagai cara pendidikan gizi. Jakarta: Bumi Aksara; 1996.

24. Emilia O. Promosi kesehatan dalam lingkup kesehatan reproduksi. Yogyakarta: Pustaka Cendekia Press; 2008.

25. Ambarwati NW, Sintowati R. Pendidikan kesehatan mengatasi keluhan hamil pada ibu-ibu hamil di asrama group II Kopassus Kartasura. Warta 2006;9(2):107-22.

26. Kaur M, Singh K. Effect health education on knowledge, attitude and practices about anaemia among rural women in Chandigarh. Indian J Community Med 2001;26(3):7-9.

27. Pribadi ET. Pemanfaatan SMS pada seluler sebagai media promosi kesehatan dalam upaya peningkatan pengetahuan dan perubahan sikap remaja mengenai aborsi [Tesis]. Surabaya: Universitas Airlangga; 2009.

28. Yekta Z, Ayatollahi H, Pourali R, Farzin A. Predicting factor in iron supplement intake among pregnant women in urban care setting. J Res Health Sci 2008;8(1):39-45.

29. Kalimbira AA, Mtimuni BM, Chilima DM. Maternal knowledge and practices related to anaemia and iron supplementation in rural Malawi. AJFAND 2009;9(1):551-64.

30. Departemen Kesehatan RI. Pedoman pemberian tablet besi-folat dan sirup besi bagi petugas. Jakarta: Dirjen Pembinaan Kesehatan Masyarakat. Direktorat Bina Gizi Masyarakat; 1999.

31. Wiknjosastro H. Ilmu kebidanan. Jakarta: Yayasan Bina Pustaka; 2007. 